\title{
PENGARUH SUPLEMENTASI DAGING IKAN MADIDIHANG (Thunnus albacares) PADA SAGU LEMPENG TERHADAP PENILAIAN ORGANOLEPTIK
}

\section{THE EFFECT OF SUPPLEMENTATION OF MEAT YELLOWFIN TUNA (Thunnus albacares) INTO SAGO PLATE TOWARD ORGANOLEPTIC ASSESSMENT}

\author{
Ahdad Hasan' ${ }^{1}$, Rinto M. Nur1 \\ ${ }^{1}$ Program Studi Teknologi Hasil Perikanan, Fakultas Perikanan dan Ilmu Kelautan Universitas \\ Pasifik Morotai Jalan. Siswa Darame, Kecamatan Morotai Selatan Kabupaten Pulau Morotai, Maluku \\ Utara
}

Korespondensi: rintomnur777@gmail.com

\begin{abstract}
ABSTRAK
Makanan harus mencukupi zat gizi yang seimbang. Suplementasi daging ikan ke dalam sagu lempeng dapat menghasilkan makanan zat gizi lengkap. Sagu lempeng yang dijual memiliki kandungan protein yang rendah. Kandungan protein sagu perlu dilakukan dengan penambahan daging ikan madidihang. Tujuan penelitian untuk mengetahui pengaruh penambahan daging ikan pada sagu lempeng. Penelitian ini menggunakan 4 perlakuan yaitu A0 (100\% ubi kayu), A1 (penambahan $15 \%$ daging ikan madidihang), A2 (penambahan 30\% daging ikan madidihang), dan A3 (penambahan 45\% daging ikan madidihang) dengan 3 kali ulangan. Tahapan meliputi pembuatan sagu lempeng dengan 4 perlakuan dan pengujian mutu organoleptik sagu meliputi penampakan, warna, aroma, rasa, dan tekstur. Hasil penelitian menunjukkan bahwa pemberian daging ikan madidihang memberikan pengaruh nyata terhadap penilaian organoleptik sagu lempeng. Nilai uji organoleptik terhadap kenampakan $(\mathrm{A} 0=7,13$; $\mathrm{A} 1=6,44 ; \mathrm{A} 2=6,95 ; \mathrm{A} 3=5,42)$, warna $(\mathrm{A} 0=7,22 ; \mathrm{A} 1=6,27 ; \mathrm{A} 2=6,92 ; \mathrm{A} 3=5,42)$ dan tekstur $(\mathrm{A} 0=7,02$; $\mathrm{A} 1=6,37 ; \mathrm{A} 2=6,20 ; \mathrm{A} 3=5,65)$ sagu lempeng oleh panelis cenderung menurun diikuti dengan kenaikan konsentrasi daging ikan yang ditambahkan. Nilai uji organoleptik aroma ( $\mathrm{A} 0=6,12 ; \mathrm{A} 1=6,25 ; \mathrm{A} 2=6,32$; $\mathrm{A} 3=6,55)$ dan rasa $(\mathrm{A} 0=6,22 ; \mathrm{A} 1=6,70 ; \mathrm{A} 2=6,92 ; \mathrm{A} 3=7,40)$ sagu lempeng oleh panelis cenderung meningkat diikuti dengan kenaikan konsentrasi daging ikan yang ditambahkan.
\end{abstract}

Kata Kunci: suplementasi, thunnus albacares, sagu lempeng, organoleptik

\begin{abstract}
Food must meet of balance nutrition. Supplementation of meat fish on the sago plate can produnce complate nutrition of nourishment. Sago plate which is sold has low protein. Sago's protein needs adding some tuna yellowfin meat. Aim of this research was to know the effect of adding fish meat into plate sago toward consumer's taste. This research used 4 treatments, they were A0 (100\% cassava), A1 (adding $15 \%$ tuna meat), A2 (adding 30\% tuna meat), A3 (adding $45 \%$ tuna meat) with 3 repetitions. Phases of this research included making of plate sago with 4 treatments and sago organoleptic quality testing consists of appearance, color, flavor, taste, and texture. Result of the research found that tuna meat gave affect on organoleptic assessment of plate sago. The value of organoleptic test toward appearance ( $\mathrm{A} 0=7,13 ; \mathrm{A} 1=6,44 ; \mathrm{A} 2=6,95 ; \mathrm{A} 3=5,42)$, color $(\mathrm{A} 0=7,22 ; \mathrm{A} 1=6,27 ; \mathrm{A} 2=6,92 ; \mathrm{A} 3=5,42)$, and texture $(\mathrm{A} 0=7,02 ; \mathrm{A} 1=6,37 ; \mathrm{A} 2=6,20 ; \mathrm{A} 3=5,65)$ of plate sago was given by panelist slightly decrease followed by an increase of the fish meat concentration that is added. At the same time, the value of organoleptic test toward flavor $(\mathrm{A} 0=6,12 ; \mathrm{A} 1=6,25 ; \mathrm{A} 2=6,32 ; \mathrm{A} 3=6,55)$ and taste $(\mathrm{A} 0=6,22$;
\end{abstract}


$\mathrm{A} 1=6,70 ; \mathrm{A} 2=6,92 ; \mathrm{A} 3=7,40)$ of plate sago was given by panelist tends to increase followed by an increase the concentration of fish meat that is added.

Keywords: supplementation, thunnus albacares, sago plate, organoleptic

\section{PENDAHULUAN}

Ikan merupakan bahan pangan yang memiliki nilai gizi tinggi dan umumnya disukai oleh masyarakat karena harganya yang relatif terjangkau. Keunggulan kandungan gizinya, ikan merupakan bahan pangan yang mudah mengalami kemunduran mutu (high perishable food) (Talib, 2019).

Sejak lama manusia telah memanfaatkan ikan sebagai bahan pangan yang banyak mengandung protein. Protein ikan sangat diperlukan oleh manusia karena selain mudah dicerna juga mengandung asam amino dengan pola yang hampir sama dengan pola asam amino yang terdapat dalam tubuh manusia (Afrianto dan Liviawaty, 2001).

Kebutuhan protein hewani yang berasal dari ikan untuk setiap orang Indonesia sekitar 3,4 gram per hari atau setara dengan $25 \mathrm{Kg}$ ikan per tahun. Namun, konsumsi rata-rata perorang hanya mencapai $18 \mathrm{Kg}$ per tahun (Irawan, 1997). Oleh sebab itu, pemerintah menganjurkan agar masyarakat lebih banyak mengonsumsi ikan untuk mendapatkan gizi yang lebih tinggi terutama bagi anak-anak. Dijen PDSPKP (2014) melaporkan bahwa pada tahun 2014 terjadi peningkatan penyediaan ikan yang diikuti dengan peningkatan konsumsi ikan. Hal ini terlihat dari peningkatan penyediaan ikan tahun 2013-2014 sebesar 8,44\% sedangkan konsumsi ikan sebesar 8,32\%.

Kecenderungan konsumen dalam mengonsumsi ikan dan turunannya terus meningkat pada tahun 2015 sebesar 41,11 kg/kap/tahun melebihi target yang telah ditentukan (40,90 kg/kap/tahun) (Abdurahman, 2015). Konsumsi ikan di Maluku Utara pada tahun 2014 sebesar 48,88 kg/kap/tahun. Di Maluku Utara, masyarakat lebih banyak mengonsumsi ikan cakalang, tuna, tongkol (CTT) dan beberapa jenis ikan pelagis dan demersal lainnya. Kecenderungan masyarakat dalam mengonsumsi ikan CTT karena mudah didapatkan. Selain itu, nilai gizi dari jenis ikan tersebut juga tergolong tinggi. Hadinoto dan Idrus (2018) melaporkan bahwa daging ikan 
madidihang atau tuna (Thunnus albacares) mengandung protein sebesar 28,34\%, kadar abu sebesar 1,48\%, dan kadar lemak sebesar 0,51\%.

Makanan harian harus mencukupi tiap jenis zat gizi yang seimbang untuk mendapatkan nilai gizi yang lebih tinggi. Namun, tidak ada satupun bahan makanan yang mengandung secara lengkap semua zat gizi dalam jumlah yang mencukupi kebutuhan tubuh. Nia et al., (2012) menyatakan bahwa tidak ada satupun bahan makanan yang mengandung zat gizi secara lengkap, maka keanekaragaman makanan yang dikonsumsi sangat penting untuk diperhatikan agar setiap makanan dapat saling melengkapi zat gizi yang tidak terkandung dalam makanan tertentu.

Sehingga, untuk mendapatkan makanan yang lebih lengkap zat gizinya dapat dilakukan dengan mensuplementasikan daging ikan ke dalam produk lain seperti mie, roti, biskuit, dan pembuatan produk tradisional seperti pembuatan sagu lempeng dengan suplementasi daging ikan.

Sagu lempeng merupakan makanan tradisional khas Maluku Utara. Sagu lempeng yang dikenal masyarakat Maluku Utara ada dua jenis yaitu sagu lempeng yang bahan bakunya dari batang pohon sagu dan dari ubi kayu. Namun, sagu lempeng berbahan baku ubi kayu lebih digemari masyarakat. Sagu lempeng yang beredar di pasaran memiliki kandungan protein yang sangat rendah.

Assagaf et al., (2009) melaporkan bahwa sagu lempeng memiliki kadar protein yang rendah $(1,43 \%)$ karena bahan sagu lempeng hanya ubi kayu yang memiliki kandungan protein rendah. Oleh sebab itu, masyarakat Maluku Utara menjadikan sagu lempeng sebagai makanan utama pengganti beras.

Meningkatkan kandungan protein sagu, maka dilakukan penambahan daging ikan. Penelitian Asy'ari dan Sidin (2019) menunjukkan bahwa penambahan daging ikan cakalang (Katsuwonus pelamis) mempengaruhi nilai organoleptik kenampakan, warna, aroma, rasa, dan tekstur sagu lempeng.

Namun, dalam penelitian ini digunakan ikan madidihang sebagai bahan suplementasi pada sagu lempeng karena merupakan ikan yang paling banyak ditangkap oleh nelayan setempat dan sangat potensial mengingat nilai gizi ikan tersebut, dagingnya memiliki serat yang halus dan berwarna putih. 
Penambahan daging ikan madidihang akan berpengaruh terhadap penampakan, warna, orama, dan tekstur sagu lempeng yang sekaligus dapat berpengaruh terhadap daya tarik masyarakat. Untuk itu, dilakukan beberapa formula dalam suplementasi daging ikan madidihang ke dalam sagu lempeng. Tujuan dilakukan penelitian ini adalah untuk meningkatkan nilai gizi sagu lempeng, dan mengetahui pengaruh penambahan daging ikan pada sagu lempeng terhadap rasa suka konsumen.

\section{METODE PENELITIAN}

\section{Jenis dan Tempat Penelitian}

Penelitian ini merupakan eksperimental dengan menggunakan 4 perlakuan yaitu A0 (100\% ubi kayu), A1 (penambahan 15\% daging ikan madidihang), A2 (penambahan 30\% daging ikan madidihang), dan A3 (penambahan 45\% daging ikan madidihang). Setiap perlakuan dlakukan tiga kali ulangan. Pembuatan sagu lempeng dilakukan di tempat pengolahan sagu milik warga Tobelo, Kabupaten Halmahera Utara, Propinsi Maluku Utara.

\section{Alat dan Bahan}

Alat yang digunakan adalah pisau, baskom, panci, mesin parut, mesin peras, pencetak sagu lempeng (forno), penjepit sagu, bambu, ayakan dan angket penilaian mutu organoleptik. Bahan penelitian adalah ubi kayu, ikan madidihang, air, dan kayu bakar.

\section{Pembuatan Sagu Lempeng}

Pembuatan sagu lempeng dimulai dengan proses ubi kayu dikupas kulitnya, dicuci dengan air bersih, kemudian diparut. Proses selanjutnya adalah pengepresan (memisahkan serat dan pati ubi kayu). Setelah dipastikan serat ubi kayu sudah kering kemudian dilakukan proses penggilingan hingga menghasilkan tepung ubi kayu (tepung sagu kasbi). Kemudian proses selanjutnya adalah pengayakan agar butiran yang masih kasar dapat digiling kembali. 
Selanjutnya disiapkan tepung/serbuk ikan madidihang dengan cara dipotong kemudian dicuci hingga bersih dan dikukus selama \pm 25 menit. Ikan yang telah matang selanjutnya diperas untuk mengurangi kadar air. Ikan yang telah diperas menjadi padatan, sehingga perlu dihauskan menjadi tepung/serbuk.

Tepung/serbuk ubi dan ikan dicampurkan sesuai formula perlakuan. Campuran serbuk ubi dan ikan dicetak menggunakan forno yang telah dipanaskan selama \pm 4 menit. Selanjutnya sagu lempeng diangkat dari forno menggunakan penjepit.

\section{Penilaian Mutu Organoleptik Sagu}

Sagu lempeng yang telah disuplementasi daging ikan madidihang selanjutnya dilakukan uji organoleptik menggunakan panelis konsumen sebanyak 20 orang (usia 15-30 tahun). Pengamatan organoleptik sagu terdiri dari penampakan, warna, aroma, rasa, dan tekstur.

\section{Analisis Data}

Data hasil uji organoleptik oleh panelis dianalisis menggunakan Analisis of Varians signifikan 5\% dan uji Duncan's Multyple Range Test signifikan 5\% menggunakan program SPSS 22.0.

\section{HASIL DAN PEMBAHASAN}

\section{Nilai Organoleptik Kenampakan}

Kenampakan merupakan keadaan keseluruhan dari sagu lempeng secara visual yang menyebabkan panelis tertarik dan suka terhadap produk tersebut. Penilaian secara visual sangat dipengaruhi oleh jenis produk, warna, intensitas penerangan, dan sudut atau jarak pengamatan (Afrianto, 2008). Berdasarkan penilaian skor sheet rata-rata uji organoleptik mutu terhadap kenampakan sagu lempeng (Tabel 1). 
Tabel 1. Nilai organoleptik kenampakan sagu lempeng ikan madidihang

\begin{tabular}{ccc}
\hline No. & Perlakuan & Rata-rata* $^{*}$ \\
\hline 1 & A0 & $7,13 \pm 0,19 \mathrm{~d}$ \\
2 & A1 & $6,44 \pm 0,25 \mathrm{c}$ \\
3 & A2 & $6,95 \pm 0,18 \mathrm{~b}$ \\
4 & A3 & $5,42 \pm 0,33 \mathrm{a}$ \\
\hline
\end{tabular}

Ket: A0 (100\% ubi kayu); A1 (penambahan daging ikan 15\%); A2 (penambahan daging ikan 30\%); A3 (penambahan daging ikan $45 \%) ; \mathrm{N}=3 ; \pm \mathrm{SD}$; angka yang diikuti huruf yang sama tidak berbeda nyata.

Semakin tinggi konsentrasi penambahan daging ikan madidihang pada sagu lempeng menyebabkan kenampakan yang dihasilkan semakin tidak menarik. Perlakuan dengan penambahan daging ikan 0, 15 dan 30\% pada sagu lempeng memperoleh nilai kenampakan masih dalam kategori menarik, karena kenampakan permukaan yang utuh dan rapih. Sedangkan perlakuan dengan penambahan daging ikan sebanyak $45 \%$ memperoleh nilai kenampakan kurang menarik karena permukaan tidak rata dan kurang rapih. Selain itu, kenampakan sagu lempeng juga kurang rapih dan permukaan tidak rata. Hal ini disebabkan karena semakin banyak daging ikan yang diberikan, maka daya lekat komponen sagu akan berkurang.

Menurut Lavlinesia (1995) bahwa rasio ikan dan tepung akan mempengaruhi daya kembang produk, dimana peningkatan kandungan protein ikan dalam adonan akan menurunkan daya kembang. Muhamad et al. (2017) juga melaporkan bahwa penambahan daging ikan berpengaruh terhadap kenampakan kecimpring karena ikan mengandung protein yang cukup tinggi.

Penambahan daging ikan pada sagu menyebabkan terbentuknya banyak rongga yang menyebabkan permukaan sagu tidak rata. Dampaknya disebabkan karena pada proses pemanasan forno (cetakan sagu lempeng) tidak dilakukan kontrol suhu, sehingga kemungkinan tidak terjadi pemerataan suhu pada masing-masing sampel maupun perlakuan. 


\section{Nilai Organoleptik Warna}

Warna merupakan salah satu faktor penentuan mutu suatu produk dan merupakan parameter awal yang secara subjektif dan visual harus dipertimbangkan karena mempengaruhi tingkat penerimaan terhadap suatu produk. Warna juga digunakan sebagai indikator kesegaran dan kematangan suatu produk. Hasil penilaian rata-rata uji organoleptik mutu terhadap warna sagu lempeng (Tabel 2).

Tabel 2. Nilai organoleptik warna sagu lempeng ikan madidihang

\begin{tabular}{ccc} 
No. & Perlakuan & Nilai Rata-rata* \\
\hline 1 & A0 & $7,22 \pm 0,26 \mathrm{c}$ \\
2 & A1 & $6,27 \pm 0,10 \mathrm{~b}$ \\
3 & A2 & $6,92 \pm 0,52 \mathrm{ab}$ \\
4 & A3 & $5,42 \pm 0,68 \mathrm{a}$ \\
\hline
\end{tabular}

Ket: A0 (100\% ubi kayu); A1 (penambahan daging ikan 15\%); A2 (penambahan daging ikan 30\%); A3 (penambahan daging ikan $45 \%) ; \mathrm{N}=3 ; \pm \mathrm{SD}$; angka yang diikuti huruf yang sama tidak berbeda nyata.

Berdasarkan hasil penilaian organoleptik terhadap warna sagu lempeng dengan penambahan daging ikan madidihang menunjukkan bahwa semakin banyak komposisi ikan yang diberikan dalam sagu, maka semakin rendah nilai yang diberikan panelis. Perlakuan dengan penambahan $0 \%$ daging ikan madidihang, rata-rata panelis memberikan nilai 7 yang menunjukkan warna sagu lempeng putih kekuning-kuningan. Sementara untuk perlakuan penambahan daging ikan sebanyak 15 dan 30\%, rata-rata panelis memberikan nilai 6 yang menunjukkan warna sagu putih sedikit kecoklatan. Rata-rata panelis memberikan nilai 5 pada sagu lempeng dengan penambahan $45 \%$ daging ikan dengan warna sagu putih coklat keabu-abuan. Rumapar (2015) melaporkan bahwa semakin tinggi konsentrasi ikan yang diberikan dalam pembuatan mie basah, menunjukkan hasil penilaian organoleptik warna mie oleh panelis semakin rendah (tidak suka).

Perubahan warna terjadi yang dipicu selama proses pengolahan ikan pada suhu tinggi dalam proses pemasakan/perebusan untuk pembuatan tepung ikan. Menurut Hadiwiyoto (1993) bahwa daging ikan mengandung protein mioglobin yang 
memberikan zat warna pada daging ikan, sehingga pada proses pemanasan dengan suhu tinggi akan terjadi reaksi browning (reaksi pencoklatan pada daging ikan yang disebabkan oleh mioglobin) yang mengakibatkan terbentuknya perubahan warna yang tidak disukai.

Kusnandar (2010) menjelaskan bahwa perubahan warna kecoklatan tersebut disebabkan oleh adanya reaksi kecoklatan nonenzimatis (reaksi Maillard). Reaksi Maillard dapat dipicu oleh pemanasan pada suhu tinggi.

\section{Nilai Organoleptik Aroma}

Aroma makanan banyak menentukan kelezatan makanan. Aroma makanan merupakan faktor dalam penentuan penerimaan makanan yang berupa molekul gas yang dapat dirasa oleh indra pembau, sehingga dapat ditentukan kelezatan produk tersebut (Winarno, 2004). Hasil penilaian rata-rata uji organoleptik mutu terhadap aroma sagu lempeng (Tabel 3).

Tabel 3. Nilai organoleptik aroma sagu lempeng ikan madidihang

\begin{tabular}{ccc}
\hline No. & Perlakuan & Nilai Rata-rata* \\
\hline 1 & A0 & $6,12 \pm 0,20 \mathrm{a}$ \\
2 & A1 & $6,25 \pm 0,15 \mathrm{a}$ \\
3 & A2 & $6,32 \pm 0,03 \mathrm{ab}$ \\
4 & A3 & $6,55 \pm 0,13 \mathrm{~b}$ \\
\hline
\end{tabular}

Ket: A0 (100\% ubi kayu); A1 (penambahan daging ikan 15\%); A2 (penambahan daging ikan 30\%); A3 (penambahan daging ikan $45 \%) ; \mathrm{N}=3 ; \pm \mathrm{SD}$; angka yang diikuti huruf yang sama tidak berbeda nyata.

Rerata nilai aroma sagu lempeng yang diberikan panelis pada perlakuan A3 lebih tinggi dibandingkan dengan perlakuan lainnya dengan spesifikasi aroma kurang harum, spesifikasi bau ikan kurang dan bau sagu kuat, tanpa bau tambahan. Sementara untuk perlakuan A0, A1 dan A2, rata-rata panelis memberikan penilaian dengan spesifikasi aroma kurang harum, spesifikasi bau ikan tidak ada dan bau sagu kuat, tanpa bau tambahan. Hal ini menunjukkan bahwa semakin banyak ikan yang ditambahkan ke dalam sagu, maka aroma ikan akan semakin kuat. Judith et al. (2016) melaporkan ahwa 
semakin banyak daging ikan yang ditambahkan pada pengolahan rengginang ubi kayu memberikan nilai aroma oleh panelis lebih tinggi.

\section{Nilai Organoleptik Rasa}

Cita rasa mempunyai peranan yang sangat penting bagi penentuan darajat penerimaan dan kualitas suatu produk atau bahan panagan. Hasil penilaian rata-rata uji organoleptik mutu terhadap rasa sagu lempeng (Tabel 4).

Tabel 4. Nilai organoleptik rasa sagu lempeng ikan madidihang

\begin{tabular}{ccc}
\hline No. & Perlakuan & Nilai Rata-rata* \\
\hline 1 & A0 & $6,22 \pm 0,10 \mathrm{a}$ \\
2 & A1 & $6,70 \pm 0,18 \mathrm{~b}$ \\
3 & A2 & $6,92 \pm 0,24 \mathrm{~b}$ \\
4 & A3 & $7,40 \pm 0,10 \mathrm{c}$
\end{tabular}

Ket: A0 (100\% ubi kayu); A1 (penambahan daging ikan 15\%); A2 (penambahan daging ikan 30\%); A3 (penambahan daging ikan $45 \%) ; \mathrm{N}=3 ; \pm \mathrm{SD}$; angka yang diikuti huruf yang sama tidak berbeda nyata.

Rerata nilai penerimaan terhadap organoleptik rasa sagu lempeng oleh panelis semakin tinggi dengan adanya peningkatan jumlah daging ikan yang ditambahkan ke dalam sagu. Perlakuan A0 mendapatkan rata-rata nilai organoleptik rasa dari panelis paling kecil $(6,22)$ dengan spesifikasi rasa enak, gurih, dan rasa ikan hilang. Hal ini disebabkan karena pada perlakuan A0 merupakan perlakuan tanpa penambahan daging ikan, sehingga tidak ada rasa ikan pada sagu lempeng dengan perlakuan tesebut.

Perlakuan A1, A2 dan A3 mendapatkan nilai rata-rata penilaian organoleptik rasa oleh panelis 6,70 — 7,40 dengan spesifikasi rasa enak, gurih, dan rasa ikan kurang. Walaupun ketiga perlakuan tersebut memiliki spesifikasi rasa yang sama, namun berdasarkan uji DMRT, perlakuan A3 berbeda nyata dengan perlakuan A1 dan A2. Asy'ari dan Sidin (2019) melaporkan bahwa penambahan daging ikan pada pengolahan sagu lempeng diperoleh penilaian yang tinggi oleh panelis terhadap nilai organoleptik rasa.

Hariyadi (2001) menjelaskan bahwa rasa pangan biasanya terdiri dari rasa asin, asam, manis, pahit, dan gurih. Beberapa faktor yang mempengaruhi rasa ditentukan 
oleh formulasi bahan yang digunakan dan biasanya tidak dipengaruhi oleh proses pengolahannya.

\section{Nilai Organoleptik Tekstur}

Penilaian terhadap tekstur berasal dari sentuhan oleh permukaan kulit. Biasanya menggunakan ujung jari tangan sehingga dapat dirasakan tekstur suatu bahan/produk. Tekstur suatu bahan tergantung dari keadaan fisi bahan tersebut sehingga penilaian terhadap tekstur dapat berupa kekerasan, kerenyahan, dan elastisitas. Hasil penilaian rata-rata uji organoleptik mutu terhadap tekstur sagu lempeng (Tabel 5).

Tabel 5. Nilai organoleptik tekstur sagu lempeng ikan madidihang

\begin{tabular}{ccc}
\hline No. & Perlakuan & Nilai rata-rata* \\
\hline 1 & A0 & $7,02 \pm 0,14 \mathrm{~b}$ \\
2 & A1 & $6,37 \pm 0,18 \mathrm{ab}$ \\
3 & A2 & $6,20 \pm 0,48 \mathrm{a}$ \\
4 & A3 & $5,65 \pm 0,15 \mathrm{a}$ \\
\hline
\end{tabular}

Ket: A0 (100\% ubi kayu); A1 (penambahan daging ikan 15\%); A2 (penambahan daging ikan 30\%); A3 (penambahan daging ikan $45 \%) ; \mathrm{N}=3 ; \pm \mathrm{SD}$; *angka yang diikuti huruf yang sama tidak berbeda nyata.

Berdasarkan uji DMRT rata-rata nilai organoleptik tekstur sagu lempeng dengan penambahan daging ikan madidihang 15, 30 dan 45\% menunjukkan nilai tidak berbeda nyata pada taraf signifikan 5\%. Rerata nilai yang diberikan oleh panelis 6 dengan spesifikasi tekstur halus, kurang padat dan kurang kompak. Hal ini disebabkan karena dengan adanya penambahan daginging ikan dalam sagu, mengurangi vikositas atau elastisitas sagu. Lawless dan Heymann (1998) menjelaskan bahwa protein akan bereaksi dengan gula dan mengurangi gelatinisasi pati.

\section{KESIMPULAN}

Dari hasil penelitian dapat disimpulkan bahwa pemberian daging ikan madidihang memberikan pengaruh nyata terhadap penilaian organoleptik sagu lempeng. Nilai uji organoleptik terhadap kenampakan, warna dan tekstur sagu lempeng 
oleh panelis cenderung menurun diikuti dengan kenaikan konsentrasi daging ikan yang ditambahkan. Sedangkan nilai uji organoleptik aroma dan rasa sagu lempeng oleh panelis cenderung meningkat diikuti dengan kenaikan konsentrasi daging ikan yang ditambahkan.

\section{DAFTAR PUSTAKA}

Abdurahman. 2015. Kebijakan Pembangunan Kelautan dan Perikanan, Kementerian Perikanan dan Kelautan.

Afrianto, E. dan Liviawaty, E. 2001. Pengawetan dan Pengolahan Ikan. Kanisius. Yogyakarta.

Afrianto. 2008. Pengawasan Mutu Bahan atau Produk Pangan. Jilid 1, untuk SMK. Direktorat Pembinaan Sekolah Menengah Kejuruan, Direktorat Jenderal Manajemen Pendidikan Dasar dan Menengah, Departemen Pendidikan Nasional. Jakarta.

Assagaf, M., Sugihono, C., Saleh, Y., Mejaya, I.M.J., dan Syahbuddin H. 2009. Teknologi Pengolahan Sagu Kasbi Aneka Rasa. Balai Pengkajian Teknologi Pertanian Maluku Utara.

Asy'ari dan Sidin, J. 2019. Uji Organoleptik Sagu Lempeng dengan Penabahan Daging Ikan Cakalang (Katsuwonus pelamis) dan Penyedap Rasa. Jurnal Ilmu-Ilmu Perikanan dan Budidaya Perairan. 14(1):23-29.

Direktorat Jenderal PSDKP. 2014. Refleksi 2014 \& Outlook 2015. Pengawasan DSKP. Jakarta.

Hadinoto, S. dan Idrus, S. 2018. Proporsi dan Kadar Proksimat Bagian Tubuh Ikan Tuna Ekor Kuning (Thunnus albacares) dari Perairan Maluku. Majalah Biam. 14(02):51-57.

Hadiwiyoto, S. 1993. Teknologi Pengolahan Hasil Perikanan. Jilid 1. Liberti. Yogyakarta.

Hariyadi, R.D. 2001. Peningkatan Peran Pusat Kajian Makanan Tradisional dalam rangka Penganekaragaman Makanan: Kajian proses Pengolahan, Khasiat dan Keamanan Makanan Tradisional Jawa Barat. Laporan Akhir. Pusat Kajian Makanan Tradisional. Bogor: Lembaga Penelitian IPB.

Irawan. 1997. Pengawetan dan Pengolahan Ikan. Kanisius. Jakarta. 
Judith, F., Buchari, D. dan Sumaroto, S. 2016. Pengaruh Penambahan Daging Ikan Patin (Pangasius hypopthalmus) pada Pengolahan Rengginag Ubi Kayu (Manihot esculenta C) terhadap Penilaian Organoleptik. Jurnal Online Mahasiswa Fakultas Perikanan dan Ilmu Kelautan Universitas Riau. 3(1):110 .

Kusnandar, F. 2010. Kimia Pangan Komponen Makro. Seri 1. Penerbit Dian Rakyat.

Lavlinesia. 1995. Kajian Beberapa Faktor Pengembang Volumetric dan Kerenyahan Kerupuk Ikan. Pascasarjana IPB. Bogor.

Muhamad, S.B., Afrianto, E.dan Kurniawati, N. 2017. Fortifikasi Daging Nila terhadap Karakteristik Organoleptik dan Kimia Kecimpring. Jurnal Perikanan dan Kelaautan. 8(1):174-178.

Nia, H.M.E., Adhi, K.T. dan Sutiari, N.K. 2012. Kecukupan Asupan Gizi Remaja Vegetarian dan Nonvegetarian di Yayasan Sri Sathya Sai Bali Tahun 2011. Indonesian Journal of Public Heatlth. 1(1):43- 49.

Rumpar, M. 2015. Fortifikasi Tepung Ikan (Decapterus sp.) pada Mie Basah yang Menggunakan Tepung Sagu sebagai Subtitusi Tepung Terigu. Majalah Biam. 11(1):26-36.

Talib, A. 2019. Diversifikasi dan Pengembangan Produk Perikanan. Raja Grafindo Persada. Depok.

Winarno, F.G. 2004. Kimia Pangan dan Gizi. Cetakan Kesebelas. PT Gramedia Pustaka Utama. Jakarta. 